\title{
Analysis of Cadets' Endurance Development at Higher Military Educational Institutions during the Kettlebell Lifting Training
}

\begin{abstract}
Kostiantyn Prontenko ${ }^{1}$, Grygoriy Griban ${ }^{2}$, Alla Aloshyna ${ }^{3}$, Ihor Bloshchynskyi ${ }^{4}$, Zhanneta Kozina ${ }^{5}$, Olexandr Bychuk ${ }^{6}$, Inesa Novitska ${ }^{7}$ and Mukola Korchagin ${ }^{8}$

'S.P. Koroliov Zhytomyr Military Institute, Department of Physical Education, Special Physical Training and Sport, Zhytomyr, Ukraine, ${ }^{2}$ Zhytomyr Ivan Franko State University, Department of Physical Education and Sport Improvement, Zhytomyr, Ukraine, '3esya Ukrainka Eastern European National University, Department of Sports-Mass Work and Tourism, Lutsk, Ukraine, ${ }^{4}$ Bohdan Khmelnytskyi National Academy of the State Border Guard Service of Ukraine, English Translation Department, Khmelnytskyi, Ukraine, ${ }^{5} \mathrm{H} . S$. Skovoroda Kharkiv National Pedagogical University, Department of Olympic and Professional Sport and Sport Games, Kharkiv, Ukraine, 'esya Ukrainka Eastern European National University, Faculty of Physical Culture, Sport and Health, Lutsk, Ukraine, 'Zhytomyr Ivan Franko State University, Department of Postgraduate and Doctorate Studies, Zhytomyr, Ukraine, ${ }^{8}$ Ivan Kozhedub Kharkiv National Air Force University, Department of Physical Education, Special Physical Training and Sport, Kharkiv, Ukraine
\end{abstract}

\begin{abstract}
The influence of the kettlebell lifting training on the level of endurance development and functional abilities of the cadets' cardiovascular system in the course of study is examined in the article. Cadets of the $1^{\text {st }}-5^{\text {th }}$ years of study ( $n=474$ ) who were studying according to the current system of physical training (group $A$, $n=416$ ) and cadets who were attending a kettlebell lifting class (group $B, n=58$ ) took part in the research. The study of the level of endurance development was conducted during the following tests: $3 \mathrm{~km}$ race, $5 \mathrm{~km}$ accelerated march, and the obstacle course $(400 \mathrm{~m})$. The cardiovascular system functioning was examined concerning these indicators: heart rate, arterial blood pressure, Robinson's index, and heart rate recovery from a standard load. The improved indicators of the endurance and cardiovascular system of group B cadets have been reliably determined $(p<0.05-0.001)$ which proves the efficiency of the kettlebell lifting training concerning the future officers' formation of physical readiness for professional activity.
\end{abstract}

Key words: endurance, cardiovascular system, cadet, kettlebell lifting

\section{Introduction}

Combat experience has shown that the winner of the battle is not only the one who is armed better, but also the one who is effectively good at the weapons and techniques, who has more developed moral combat characteristics, endurance, commitment to success, physical abilities, resistance to emotional and mental loads (Finogenov, 2015; Habchuk, 2016; Rolyuk et al., 2016). Modern professional military (combat) activity is connected with many negative factors, worsening the physical condition, working capaci- ty of military servicemen and combat capability of military units. That is why the significance of the physical training for the increase of combat capability of units and military servicemen's resistance to various negative factors of modern combat is increased (Kamaiev et al., 2018; Pichugin, Griban, \& Romanchuk, 2011). The analysis of the results of the scientific researches which military servicemen of different military specialties were involved in, showed that the efficiency of their professional activity mostly depends on the development of such physical qualities as endurance and strength

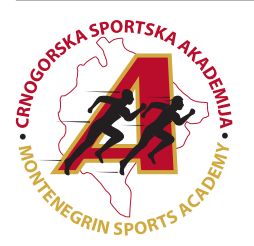

Correspondence:

K.V. Prontenko

S.P. Koroliov Zhytomyr Military Institute, Department of Physical Education, Special Physical Training and Sport, Zhytomyr, Ukraine E-mail: prontenko-kostya@ukr.net 
(Abdullah et al., 2016; Bolotin, Bakayev, \& Vazhenin, 2016; Grankin \& Kuznecova, 2017; Oderov et al., 2017). The high level of endurance development ensures the improvement of the functional abilities of the main life support systems, especially the cardiovascular system (Cobar \& Madrigal, 2016; Gardasevic, Bjelica, \& Corluka, 2018; Karim \& Jabbar, 2018; Shephard \& Astrand, 1992).

The analysis of the literature sources (Beauchamp \& Pike, 2006; Manocchia, Spierer, Lufkin, Minichiello, \& Castro, 2013; Oleshko, 2011; Vatel \& Gray, 2005) shows that kettlebell lifting is one of the effective means of physical training which ensures strength and endurance development. The exercises with kettlebells promote effective development of physical and moral characteristics, volitional powers, functional abilities of the cardiovascular and respiratory systems and supporting-motor apparatus improvement (Ambrozy et al., 2017; Kruszewski et al., 2017; Maulit et al., 2017). Besides, simplicity of the exercises in kettlebell lifting, compactness of the equipment, possibility to carry out training alone and with a group at the gym, in the sports part of the military barrack and in the open air, low accident rate, the simplicity and economic efficiency of the materials supply (Griban, K. Prontenko, \& V. Prontenko, 2014; Kuzmin, 2003; Prontenko et al., 2018) means that kettlebell lifting training of the cadets will ensure the working capacity increase in the process of studying and future professional military activity.

The aim of the article is to investigate the influence of the kettlebell lifting training on the level of endurance development and functional abilities of cadets' cardiovascular system in the course of their study.

\section{Methods}

The research was conducted with the cadets of 1 st to 5 th years of study $(n=474)$ of S.P. Koroliov Zhytomyr Military Institute, who were engaged in the current system of physical training (group $\mathrm{A}, \mathrm{n}=416$ ), and also with the cadets who were attending the kettlebell lifting class during their study (group $\mathrm{B}, \mathrm{n}=58$ ).

The research of the level of development of cadets' endurance was carried out according to the following tests: 3 $\mathrm{km}$ race, $5 \mathrm{~km}$ accelerated march, overcoming of the obstacle course $(400 \mathrm{~m})$. The performance of the cardiovascular system was examined concerning these indicators: heart rate, arterial blood pressure, Robinson's index, and heart rate recovery from a standard load. The Robinson's index characterizes the performance of the cardiovascular system. The decrease of the indicator determines improvement in the system functioning. The Robinson's index in standard units was determined based on the product of heart rate and systolic blood pressure divided by 100 . The research of the heart rate recovery was held after 20 squats in 30 seconds. The examination of the exercises was conducted by the instructors of Physical Education, Special Physical Training and Sport Department during the exams. The examination of the cardiovascular system functioning was carried out by the medical personnel of the institution. The significance of the difference in the results of the cadets was determined during the studying based on the Student's test and the dynamics of the results was investigated in both groups. The significance for all statistical tests was set at $p<0.05$. All statistical analyses were performed with the SPSS software, version 21 , adapted to medical and biological researches.

This study complies with the ethical standards of the Order of the Minister of Defense of Ukraine "on Approval of the Regulation on the Organization of Scientific and Technical Activity in the Armed Forces of Ukraine" No. 385 dated 27.07.2016.

The methods of the research: theoretical analysis and generalization of the scientific and methodological literature, pedagogic observation, biomedical methods, testing and methods of mathematical statistics.

\section{Results}

The analysis of the results in the $3 \mathrm{~km}$ race showed that the indicators of endurance development of the cadets from both groups do not differ significantly $(\mathrm{p}>0.05)$ during the 1 st and 2 nd years of study (Table 1). Starting from the 3 rd year of study, the results of the $3 \mathrm{~km}$ race of the cadets who were engaged in kettlebell lifting started to be higher in comparison to the results of the cadets who were studying according to the current system of physical training at higher military educational institutions (HMEI) $(\mathrm{p}<0.05-$ $0.001)$. Thus, the results of group B (11 min $46 \mathrm{sec}$ ) are 29.5 $\mathrm{sec}$ better than the results of group A $(12 \mathrm{~min} 15 \mathrm{sec})$ in the 3 rd year of study $(\mathrm{p}<0.05)$, the results of group B $(11 \mathrm{~min}$ $31 \mathrm{sec})$ are $30.8 \mathrm{sec}$ better than the results of group A (12 min $02 \mathrm{sec})$ in the 4 th year of study $(\mathrm{p}<0.05)$, the difference in the results of group B $(11 \mathrm{~min} 22 \mathrm{sec})$ and group A (11 $\min 58 \mathrm{sec})$ is $36.2 \mathrm{sec}$ in the 5 th year of study $(\mathrm{p}<0.01)$. The study of the results changes in the $3 \mathrm{~km}$ race of the cadets of every group determined that the changes are positive in both groups. However, the level of endurance development of the cadets of the 5 th year of study is $1 \mathrm{~min} 11 \mathrm{sec}$ better than the level of the cadets of the 1st year of study in group $A(p<0.001)$ and the changes are more prominent in group $\mathrm{B}$ - the difference in the results of kettlebell lifters of the 5 th and the 1 st years of study is $1 \mathrm{~min} 53 \mathrm{sec}(\mathrm{p}<0.001)$. The level of endurance development of the cadets of both groups was rated as adequate in the 1st year of study, as good in group $\mathrm{A}$ in the $2 \mathrm{nd}$, 3rd and 4 th years of study and as excellent in the 5th year of study. The cadets' of group B level was rated as excellent in the 2 nd - 5 th years of study that means the positive influence of the kettlebell lifting training on the level of endurance development.

The analysis of the results in $5 \mathrm{~km}$ accelerated march proves the high level of endurance development of the cadets who were attending kettlebell lifting class. Thus, the results of the cadets of group B are $16.7 \mathrm{sec}$ better than the results of the cadets of group A only in the 1st year of study $(p>0.05)$ and the results of the kettlebell lifters are better than the results of the cadets who were studying according to the current system of physical training at HMEI in the other years of study $(\mathrm{p}<0.001)$ (Table 1$)$.

The difference is $1 \mathrm{~min} 05 \mathrm{sec}$ in the 2 nd year of study, 1 min $11 \mathrm{sec}$ - in the $3 \mathrm{rd}$ year of study, $1 \mathrm{~min} 12 \mathrm{sec}$ - in the 4 th year of study, $1 \mathrm{~min} 02 \mathrm{sec}$ - in the 5 th year of study. The changes in the results in $5 \mathrm{~km}$ accelerated march proves that the kettlebell lifting training ensures endurance development more effectively - the difference in the results of the cadets of the 5 th $(19 \mathrm{~min} 51 \mathrm{sec})$ and the $1 \mathrm{st}(22 \mathrm{~min} 58 \mathrm{sec})$ years of study is $3 \mathrm{~min} 07 \mathrm{sec}$ in group $\mathrm{B}(\mathrm{p}<0.001)$; the results of the cadets in the 5 th year of study are $2 \mathrm{~min} 22 \mathrm{sec}$ better than in the 1 st year of study in group $\mathrm{A}(\mathrm{p}<0.001)$. 
Table 1. The Level and Dynamics of Endurance Development of the Cadets group A and the Cadets group $B(n=474)$

\begin{tabular}{|c|c|c|c|c|c|}
\hline \multirow{2}{*}{ Years of study } & \multicolumn{2}{|c|}{ Group A ( $n=416)$} & \multicolumn{2}{|c|}{ Group B $(n=58)$} & \multirow{2}{*}{$\begin{array}{c}\text { Confidence } \\
\text { intervals }\end{array}$} \\
\hline & $\mathbf{N}$ & Mean \pm SD & $\mathbf{N}$ & Mean \pm SD & \\
\hline \multicolumn{6}{|c|}{$3 \mathrm{~km}$ race, sec } \\
\hline 1 & 62 & $789.3 \pm 8.19$ & 16 & $795.2 \pm 13.42$ & $p>0.05$ \\
\hline 2 & 112 & $757.4 \pm 7.66$ & 9 & $729.4 \pm 13.17$ & $p>0.05$ \\
\hline 3 & 91 & $735.2 \pm 7.93$ & 14 & $705.7 \pm 12.10$ & $\mathrm{p}<0.05$ \\
\hline 4 & 76 & $722.1 \pm 7.86$ & 12 & $691.3 \pm 10.93$ & $\mathrm{p}<0.05$ \\
\hline 5 & 75 & $717.8 \pm 7.34$ & 7 & $681.6 \pm 11.21$ & $\mathrm{p}<0.01$ \\
\hline \multicolumn{6}{|c|}{$5 \mathrm{~km}$ accelerated march, sec } \\
\hline 1 & 62 & $1394.9 \pm 7.73$ & 16 & $1378.2 \pm 14.07$ & $p>0.05$ \\
\hline 2 & 112 & $1347.1 \pm 5.28$ & 9 & $1282.3 \pm 13.84$ & $\mathrm{p}<0.001$ \\
\hline 3 & 91 & $1306.3 \pm 5.91$ & 14 & $1234.9 \pm 12.95$ & $\mathrm{p}<0.001$ \\
\hline 4 & 76 & $1279.0 \pm 6.79$ & 12 & $1207.2 \pm 13.15$ & $\mathrm{p}<0.001$ \\
\hline 5 & 75 & $1252.6 \pm 6.73$ & 7 & $1190.8 \pm 13.62$ & $\mathrm{p}<0.001$ \\
\hline \multicolumn{6}{|c|}{ Overcoming the obstacle course $(400 \mathrm{~m})$, sec } \\
\hline 1 & 62 & $143.1 \pm 1.69$ & 16 & $146.0 \pm 1.82$ & $p>0.05$ \\
\hline 2 & 112 & $137.8 \pm 1.27$ & 9 & $137.4 \pm 2.73$ & $p>0.05$ \\
\hline 3 & 91 & $132.2 \pm 1.34$ & 14 & $129.2 \pm 2.08$ & $p>0.05$ \\
\hline 4 & 76 & $126.9 \pm 1.30$ & 12 & $122.8 \pm 2.65$ & $p>0.05$ \\
\hline 5 & 75 & $123.3 \pm 1.52$ & 7 & $118.2 \pm 2.21$ & $\mathrm{p}<0.05$ \\
\hline
\end{tabular}

Legend: $\mathrm{N}$ - number of subjects; Mean - arithmetical average; SD - standard deviation

According to the cadets' from group A $5 \mathrm{~km}$ accelerated march results, the level of endurance development is rated as adequate in the 1 st year of study, good in the 2 nd -4 th years of study, excellent in the 5th year of study. The results of the cadets from group B are rated as good only in the 1st year of study and excellent in the 2 nd - 5th years of study.

The study of the results in overcoming the obstacle course proves that the indicators did not differ significantly in the 1 st and 2 nd years of study ( $>0.05)$ (Table 1$)$. The results of the kettlebell lifters of the 3rd and 4th years of study are 3 and $4.1 \mathrm{sec}$ better respectively than the result of the group A cadets, but the significant difference has not been determined ( $p>0.05)$. The results of group B are $5.1 \mathrm{sec}$ better than the re- sults of group $A$ in the 5 th year of study $(\mathrm{p}<0.05)$. The changes in the results of the cadets of both groups are positive - the best results are determined in the 5th year of study: the result in group A is 2 min $03 \mathrm{sec}$ which is $19.8 \mathrm{sec}$ better than the results in the 1st year of study ( $2 \min 23 \mathrm{sec})(\mathrm{p}<0.001)$, the result in group B is $1 \mathrm{~min} 58 \mathrm{sec}$ which is $27.8 \mathrm{sec}$ better than the results in the 1st year of study $(2 \mathrm{~min} 26 \mathrm{sec})(\mathrm{p}<0.001)$. The comparison of the results in overcoming the obstacle course with normative requirements concerning the year of study proves that the results of the cadets in the last years of study are rated as good in group A and excellent in group B. It shows the positive influence of the kettlebell lifting training on the physical qualities of the cadets who are future officers.

Table 2. The Level and Dynamics of the Cardiovascular System Indicators of the Cadets group $A$ and the Cadets group $B(n=474)$

\begin{tabular}{|c|c|c|c|c|c|}
\hline \multirow{2}{*}{ Years of study } & \multicolumn{2}{|c|}{ Group A (n=416) } & \multicolumn{2}{|c|}{ Group B $(n=58)$} & \multirow{2}{*}{$\begin{array}{c}\text { Confidence } \\
\text { intervals }\end{array}$} \\
\hline & $\mathbf{N}$ & Mean \pm SD & $\mathbf{N}$ & Mean \pm SD & \\
\hline \multicolumn{6}{|c|}{ Heart beat at rest, bpm } \\
\hline 1 & 62 & $71.3 \pm 0.67$ & 16 & $71.0 \pm 1.41$ & $p>0.05$ \\
\hline 2 & 112 & $70.8 \pm 0.55$ & 9 & $69.3 \pm 1.86$ & $p>0.05$ \\
\hline 3 & 91 & $70.5 \pm 0.61$ & 14 & $67.4 \pm 1.32$ & $\mathrm{p}<0.05$ \\
\hline 4 & 76 & $69.2 \pm 0.64$ & 12 & $64.8 \pm 1.36$ & $\mathrm{p}<0.01$ \\
\hline 5 & 75 & $70.7 \pm 0.66$ & 7 & $62.5 \pm 1.29$ & $\mathrm{p}<0.001$ \\
\hline \multicolumn{6}{|c|}{ Systolic blood pressure, $\mathrm{mmHg}$} \\
\hline 1 & 62 & $122.3 \pm 0.61$ & 16 & $121.7 \pm 1.35$ & $p>0.05$ \\
\hline 2 & 112 & $121.8 \pm 0.48$ & 9 & $120.3 \pm 1.57$ & $p>0.05$ \\
\hline 3 & 91 & $121.5 \pm 0.53$ & 14 & $119.6 \pm 1.41$ & $p>0.05$ \\
\hline 4 & 76 & $120.9 \pm 0.58$ & 12 & $118.9 \pm 1.44$ & $p>0.05$ \\
\hline 5 & 75 & $121.2 \pm 0.50$ & 7 & $118.1 \pm 1.46$ & $\mathrm{p}<0.05$ \\
\hline \multicolumn{6}{|c|}{ Diastolic blood pressure, $\mathrm{mmHg}$} \\
\hline 1 & 62 & $72.5 \pm 0.58$ & 16 & $72.0 \pm 0.84$ & $p>0.05$ \\
\hline 2 & 112 & $72.1 \pm 0.40$ & 9 & $70.9 \pm 0.87$ & $p>0.05$ \\
\hline
\end{tabular}




\begin{tabular}{|c|c|c|c|c|c|}
\hline \multirow{2}{*}{ Years of study } & \multicolumn{2}{|c|}{ Group A ( $n=416)$} & \multicolumn{2}{|c|}{ Group B $(n=58)$} & \multirow{2}{*}{$\begin{array}{c}\text { Confidence } \\
\text { intervals }\end{array}$} \\
\hline & $\mathbf{N}$ & Mean \pm SD & $\mathbf{N}$ & Mean \pm SD & \\
\hline \multicolumn{6}{|c|}{ Diastolic blood pressure, $\mathrm{mmHg}$} \\
\hline 3 & 91 & $71.3 \pm 0.43$ & 14 & $69.9 \pm 0.85$ & $p>0.05$ \\
\hline 4 & 76 & $70.6 \pm 0.45$ & 12 & $68.7 \pm 0.79$ & $\mathrm{p}<0.05$ \\
\hline 5 & 75 & $71.9 \pm 0.48$ & 7 & $67.8 \pm 0.81$ & $p<0.001$ \\
\hline \multicolumn{6}{|c|}{ Robinson's index, s. u. } \\
\hline 1 & 62 & $87.19 \pm 0.81$ & 16 & $86.41 \pm 1.82$ & $p>0.05$ \\
\hline 2 & 112 & $86.23 \pm 0.65$ & 9 & $83.36 \pm 2.38$ & $p>0.05$ \\
\hline 3 & 91 & $85.65 \pm 0.69$ & 14 & $80.61 \pm 1.94$ & $p<0.05$ \\
\hline 4 & 76 & $83.66 \pm 0.73$ & 12 & $77.04 \pm 2.51$ & $\mathrm{p}<0.05$ \\
\hline 5 & 75 & $85.69 \pm 0.79$ & 7 & $73.81 \pm 2.67$ & $p<0.001$ \\
\hline \multicolumn{6}{|c|}{ Heart rate recovery after 20 squats in 30 seconds, sec } \\
\hline 1 & 62 & $132.1 \pm 2.58$ & 16 & $134.6 \pm 4.45$ & $p>0.05$ \\
\hline 2 & 112 & $125.6 \pm 1.96$ & 9 & $117.5 \pm 4.37$ & $p>0.05$ \\
\hline 3 & 91 & $121.3 \pm 2.05$ & 14 & $103.8 \pm 3.12$ & $\mathrm{p}<0.001$ \\
\hline 4 & 76 & $118.5 \pm 2.27$ & 12 & $95.2 \pm 3.28$ & $\mathrm{p}<0.001$ \\
\hline 5 & 75 & $116.9 \pm 2.45$ & 7 & $88.1 \pm 3.21$ & $\mathrm{p}<0.001$ \\
\hline
\end{tabular}

Legend: $\mathrm{N}$ - number of subjects; Mean - arithmetical average; SD - standard deviation

The analysis of the heart rate of the cadets showed that the difference in the results of group $A$ and group $B$ is not discovered in the 1 st and 2 nd years of study ( $p>0.05)$. The significant difference in the results of the cadets is discovered in the last years of study: the indicators of the heart rate of the kettlebell lifters is $3.1 \mathrm{bpm}$ better than the indicators of the cadets who were studying according to the current system of physical training in the 3 rd year of study $(\mathrm{p}<0.05)$, $4.4 \mathrm{bpm}$ - in the 4 th year of study $(\mathrm{p}<0.01), 8.2 \mathrm{bpm}$ in the 5 th year of study $(\mathrm{p}<0.001)$ (Table 2$)$. The study of the heart rate changes in every group during studying proves that the average indicators of the heart rate in both groups have the upward trend - the indicators of the cadets of the 5 th year of study in both groups A and B are better than in the 1st year of study. However, the difference in the heart rate indicators of the cadets of the 5 th and the 1 st years of study is $0.6 \mathrm{bpm}$ in group $A(p>0.05)$ and $8.5 \mathrm{bpm}$ in group $\mathrm{B}(\mathrm{p}<0.001)$.

The examination of the blood pressure shows that the indicators of the systolic blood pressure are the same in both groups A and B in the 1 st - 4th years of study ( $p>0.05)$. The difference is discovered in the 5 th year of study - the indicators of the systolic blood pressure of the kettlebell lifters are $3.1 \mathrm{mmHg}$ better than the indicators of the cadets studying according to the current system of physical training $(\mathrm{p}<0.05)($ Table 2$)$. The analysis of the diastolic blood pressure shows similar dynamics of the indicators: the indicators are the same in both groups A and B in the 1st - 3rd years of study $(p>0.05)$ and the indicators of the cadets from group $\mathrm{B}$ are 1.9 and $4.1 \mathrm{mmHg}$ better than the indicators of the cadets from group $\mathrm{A}$ in the 4 th and 5 th years of study respectively $(\mathrm{p}<0.05 ; \mathrm{p}<0.001)$. The study of the blood pressure changes in every group during studying proves that the indicators of both systolic and diastolic blood pressure have the upward trend in both groups. However, in group $\mathrm{A}$, the difference in the blood pressure indicators of the cadets of the 1st and the 5th years of study is 1.1 and 0.6 $\mathrm{mmHg}$ respectively and it is not authentic ( $\mathrm{p}>0.05)$ and in group $\mathrm{B}$, the difference is $3.6 \mathrm{mmHg}$ in systolic blood pressure $(\mathrm{p}>0.05)$ and $4.2 \mathrm{mmHg}$ in diastolic blood pressure $(\mathrm{p}<0.01)$.

The analysis of the Robinson's index showed that the difference in the indicators of group A and group B is not discovered in the 1 st and 2 nd years of study $(p>0.05)$. The Robinson's index of the cadets who were attending kettlebell lifting class is discovered to be $5.04 \mathrm{~s}$. u. better in the $3 \mathrm{rd}$ year of study $(\mathrm{p}<0.05), 6.62 \mathrm{~s}$. $\mathrm{u}$. in the 4 th year of study $(\mathrm{p}<0.05), 11.88 \mathrm{~s} . \mathrm{u}$. in the 5 th year of study $(\mathrm{p}<0.001)$ than the Robinson's index of the cadets who were studying according to the current system of physical training (Table 2), that proves the positive influence of the kettlebell lifting on the improvement of the functional abilities of the cadets' cardiovascular system. The study of the Robinson's index changes determined that the indicators improved till the 4 th year of study $(\mathrm{p}<0.01)$, but worsened in group $A$ in the 5 th year of study. Moreover, the indicators of the Robinson's index of the cadets of the 5 th year of study do not differ from the indicators of the cadets of the 1st year of study ( $p>0.05)$, the difference is $1.5 \mathrm{~s}$. u. In group $\mathrm{B}$, the upward trend is defined concerning the functional abilities of the cardiovascular system of the kettlebell lifters during the studying - the indicators of the 5 th year of study are $12.6 \mathrm{~s}$. u. better than the indicators of the 1 st year of study $(\mathrm{p}<0.001)$.

The analysis of the heart rate recovery after 20 squats in 30 seconds showed that the indicators were the same in the 1 st and 2 nd years of study ( $p>0.05)$. The heart rate recovery of the kettlebell lifters is determined to be $17.5 \mathrm{sec}$ better in the 3rd year of study $(\mathrm{p}<0.001), 23.3 \mathrm{sec}$ better in the 4th year of study $(p<0.001), 26.8 \mathrm{sec}$ better in the 5 th year of study $(p<0.001)$ than the heart rate recovery of the cadets who were studying according to the current system of physical training (Table 2). The analysis of the indicators changes of the cardiovascular system functioning recovery showed that the heart rate recovery is improved in both groups. However, the difference in the indicators of the cadets of the 5th and the 1st years of study is $15.2 \mathrm{sec}$ in group A and $46.5 \mathrm{sec}$ in group $\mathrm{B}(\mathrm{p}<0.001)$, that emphasizes the positive influence of the kettlebell lifting training on the cardiovascular system functioning improvement. 


\section{Discussion}

The principle of kettlebell lifting is to lift weights as many times as possible in a definite period of time. Modern competitions in kettlebell lifting measure this period by 10 or 12 minutes (Beauchamp \& Pike, 2006; Griban et al., 2014; Prontenko et al., 2017). In biathlon sportsmen do two exercises, each takes 10 minutes. According to the data of scientists (Kuzmin, 2003; Manocchia et al., 2013), who write about physiologic characteristics of kettlebell lifting in their works, during only one exercises in kettlebell lifting sportsmen lift more than 10 tons in 10 minutes. The authors equal the competitive work in kettlebell lifting to overcoming the distance of $10-15 \mathrm{~km}$ in speed skiing concerning the energy consumption (Tikhonov, Sukhovey, \& Leonov, 2009). The scientists (Ambrozy et al., 2017; Grankin \& Kuznecova, 2017; Kruszewski et al., 2017; Manocchia et al., 2013) mention that kettlebell lifting place high demands to the cardiorespiratory system of sportsmen and that the improvement of the results in kettlebell lifting correlates with the indicators of step-test, timed inspiratory capacity, $3 \mathrm{~km}$ race that proves high level of endurance development of the kettlebell lifters. The authors mention that systematic kettlebell lifting training makes the volume of cardiac muscle and blood vessels larger; changes blood composition (increase the quantity of erythrocytes and hemoglobin) (Oleshko, 2011; Tikhonov et al., 2009; Vatel \& Gray, 2005).

From the physiological point of view, the endurance is the ability to perform work continually with definite intensity, the ability to deal with the exhaustion (Krivokapic, 2017; Wilmore \& Costiill, 2004). The endurance allows performing the work which involves many muscle groups and places high demands on the cardiovascular and respiratory systems continuously (Costa et al., 2016; Platonov, 2004). The examination of the influence of kettlebell lifting on the functional state of the cadets' organisms defined that the kettlebell lifting training ensures heart rate decrease, stabilization of the blood pressure at rest, accelerated recovery process. Besides, the results in $3 \mathrm{~km}$ race, $5 \mathrm{~km}$ accelerated march, overcoming the obstacle course by the cadets who were attending a kettlebell lifting class are defined to be better $(p<0.05-0.001)$ than the results of the cadets who were studying according to the current system of physical training. It proves the efficiency of the kettlebell lifting training during studying concerning the formation of physical readiness of the future officers for the professional activity.

The positive influence of the kettlebell lifting training on the level of endurance development and functional abilities of the cardiovascular system of the cadets have been determined. Thus, the results in $3 \mathrm{~km}$ race, $5 \mathrm{~km}$ accelerated march, overcoming the obstacle course, indicators of heart beat, Robinson's index and heart rate recovery of the cadets who were attending a kettlebell lifting class are better during the last years of study than those of the cadets who were studying according to the current system of physical training $(\mathrm{p}<0.05-0.001)$. The high level of endurance development and functional abilities of the cardiovascular system of the cadets who were attending a kettlebell lifting class will ensure the improvement of their future performance of the professional activity.

\section{Acknowledgements}

There are no acknowledgements.

\section{Conflict of Interest}

The authors declare that there are no conflicts of interest.

Received: 14 March 2019| Accepted: 02 May 2019| Published: 01 June 2019

\section{References}

Abdullah, M.R., Eswaramoorthi, V., Musa, R.M., Maliki, Ab., Kosni, N.A., \& Haque, M. (2016). The effectiveness of aerobic exercises at difference intensities of managing blood pressure in essential hypertensive information technology officers. Journal of Young Pharmacists, 8(4), 483486. doi: 10.5530/jyp.2016.4.27

Ambrozy, T., Kiszczak, L., Omorczyk, J., Ozimek, M., Palka, T., Mucha, D., Stanula, A., \& Mucha, D. (2017). Influence of experimental training with external resistance in a form of «kettlebell» on selected components of women's physical fitness. Baltic Journal of Health and Physical Activity, 9(1), 28-36

Beauchamp, R., \& Pike, S. (2006). The Kettlebell bible: UK Bear Publishing.

Bolotin, A., Bakayev, V., \& Vazhenin, S. (2016). Pedagogical model for developing skills required by cadets of higher education institutions of the Aerospace Forces to organize their kettlebell self-training. Journal of Physical Education and Sport, 16(1), 177-186. doi:10.7752/ jpes.2016.01028

Cobar, A. G., \& Madrigal, N. (2016). Effect of endurance training with weighted vest on the 3000 meter running time of high school boys. Journal of Physical Education and Sport, 16(2), 301-310. doi:10.7752/ jpes.2016.02048

Costa, A.M., Gil, M.H., Sousa, A.C., Ensinas, V., Espada, M.C., \& Pereira, A. (2016). Effects of concurrent strength and endurance training sequence order on physical fitness performance in adolescent students. Journal of Physical Education and Sport, 16(4), 1202-1206. doi:10.7752/ jpes.2016.04191

Finogenov, Yu.S. (2015). Methodical recommendations to organization of physical training in a special period: NUDU.

Gardasevic, J., Bjelica, D., \& Corluka, M. (2018). The impact of the preparation period on endurance at football players U16. Sport Mont, 16(1), 21-24. doi 10.26773/smj.180204

Grankin, N.A., \& Kuznecova, Z.M. (2017). Indices of functional state and reserve opportunities of cadets. Pedagogical-psychological and medico-biological problems of physical culture and sports, 12(1), 37-46. doi $10.14526 / 03 \quad 2017232$

Griban, G.P., Prontenko, K.V., \& Prontenko, V.V. (2014). Kettlebell lifting in higher education establishments: Ruta.

Habchuk, A.O. (2016). Organization of special physical training in the higher military educational institutions taking into account Antiterrorist operation experience: $\mathrm{ZMI}$.

Kamaiev, O.I., Hunchenko, V.A., Mulyk, K.V., Hradusov, V.A., Homanyuk, S.V., Mishyn, M.V., Martynenko, O.M., \& Shuryaev, V.P. (2018). Optimization of special physical training of cadets in the specialty «Arms and Military Equipment» on performing professional military-technical standards. Journal of Physical Education and Sport, 18(Supplement issue 4), 1808-1810. doi:10.7752/jpes.2018.s4264

Karim, A.A., \& Jabbar, B. (2018). Effects of hypobaric endurance training on graded exercise induced lymphocyte mobilization, senescence and their surface thiol levels in elite male athletes. International Journal of Applied Exercise Physiology, 7(1), 48-55. doi: 10.22631/ijaep.v7i1.227

Krivokapic, D. (2017). Theories of tiredness in sport. Sport Mont 15(1), 3537.

Kruszewski, M., Kruszewski, A., Kuzmicki, S., Korczak, R., Tabecki, R., Landowski, K., et al. (2017).The effectiveness of kettlebell exercises in the aspects of special efficiency training in American football. Baltic Journal of Health and Physical Activity, 9(3), 53-62.

Kuzmin, A.A. (2003). Kettlebell sport: Iron sport for iron men. Methods of training by Andrey Kuzmin: Ohio.

Manocchia, P., Spierer, D.K. Lufkin, A. K. Minichiello, J., \& Castro, J. (2013). Transference of kettlebell training to strength, power, and endurance. Journal of Strength and Conditioning Research, 27(2), 477-484. doi: 10.1519/JSC.0b013e31825770fe.

Maulit, M.R., Archer, D.C., Leyva, Wh.D., Munger, C.N., Wong, M.A., Brown, L.E., et al. (2017). Effects of kettlebell swing vs. explosive deadlift training on strength and power. International Journal of Kinesiology \& Sports Science, 5(1), 1-7. doi:10.7575/aiac.ijkss.v.5n.1p.1

Oderov, A., Romanchuk, S., Fedak, S., Kuznetsov, M., Petruk, A., Dunets-Lesko, A., et al. (2017). Innovative approaches for evaluating physical fitness of servicemen in the system of professional training. Journal of Physical Education and Sport, 17(Supplement issue 1), 23-27. doi:10.7752/jpes.2017.s1004

Oleshko, V.G. (2011). The preparedness of sportsmen in the power types of sport: DIA. 
Pichugin, M.F., Griban, G.P., \& Romanchuk, V.M. (2011). Physical education of military servicemen: ZMINAU.

Platonov, V.N. (2004). The system of preparations of sportsmen in Olympic sport: Olympic literature.

Prontenko, K., Griban, G., Prontenko, V., Andreychuk, V., Tkachenko, P., Kostyuk, $\mathrm{Yu}$., et al. (2017). Kettlebell lifting as a means of physical training cadets in higher military educational institution. Journal of Physical Education and Sport, 17(4), 2685-2689. doi:10.7752/jpes.2017.04310

Prontenko, K., Griban, G., Prontenko, V., Opanasiuk, F., Tkachenko, P., Zhukovskyi, Ye., et al. (2018). Health improvement of cadets from higher military educational institutions during kettlebell lifting activities. Journal of Physical Education and Sport, 18(1), 298-303. doi:10.7752/jpes.2018.01040
Rolyuk, A., Romanchuk, S., Romanchuk, V., Boyarchuk, A., Kyrpenko, V., Afonin, $V$., et al. (2016). Research on the organism response of reconnaissance officers on the specific load of military exercises. Journal of Physical Education and Sport, 16(1), 132-135. doi:10.7752/jpes.2016.01022

Shephard, R.J., \& Astrand, P.O. (1992). Endurance in Sport: Oxford.

Tikhonov, V.F., Sukhovey, A.V., \& Leonov, D.V. (2009). Basis of kettlebell lifting. Motor actions teaching and training methods: Sovet. sport.

Vatel, S., \& Gray, V.D. (2005). Kettlebells: Strength training for power and grace: New York Sterling Publishing.

Wilmore, J.H., \& Costiill, D.L. (2004). Physiology of Sport and Exercise: Champaign, Illinois. 